Simona ZAVRATNIK*

\title{
MIGRANTI IN MIGRANTSKO DELO V ČASU PANDEMIJE ${ }^{* *}$
}

\begin{abstract}
Povzetek. Članek analizira družbenoekonomske učinke pandemije Covida-19 na migracije v kontekstu novega režima (ne)mobilnosti, $v$ katerem so se mednarodne migracije močno zmanjšale. Na podlagi najnovejših analiz in poročil globalnih akterjev mobilnosti preizkušamo tezo, da so migranti ostali na delovnih mestih, da smo "drugi lahko delali od doma. Migrantsko delo je pomembno za relativno nemoteno funkcioniranje družbe v obdobju največje zdravstvene krize; odvisnost nacionalnih ekonomij od migrantskega dela pa je stalnica, ki jo je pandemija še zaostrila. Analiza kaže, da migrantski delavci $v$ času omejene fizične mobilnosti (kot del globalnega prekariata in "novih revnih", ki jih je ustvarila pandemija) prispevajo $k$ sistemskemu delovanju družbe. V ožjem vidiku analize se kaže precejšnja odpornost migrantskega dela, o čemer priča skorajda nespremenjen obseg denarnih nakazil migrantov $v$ pandemičnem letu 2020.

Ključni pojmi: migrantski delavci, pandemija Covid-19, trg dela, denarna nakazila migrantov, novi revni
\end{abstract}

\section{Uvod}

Vseprisoten in še vedno dramatičen vpliv pandemije Covida-19 na družbeno življenje širom sveta, vključno z mednarodnimi migracijami in splošno čezmejno mobilnostjo ljudi, se leta 2021 ni ustavil. Meje so v pandemiji postale selekcionirano (ne)prehodne tudi za državljane, ne le za migrante in begunce; tovrstni procesi »migrantizacije državljanov« (Anderson, 2019) pa so pomembna novost v proučevanju čezmejne mobilnosti. Srečujemo se s spremenjeno realnostjo v polju mobilnosti, po oceni Združenih narodov

* Dr. Simona Zavratnik, docentka, Fakulteta za družbene vede, Univerza v Ljubljani, Slovenija.

** Članek je nastal v okviru raziskovalnega programa Sociološki vidiki trajnostnega družbenoprostorskega in kadrovskega razvoja Slovenije v Evropi (P5-0181) in projekta Politični in medijski populizem. "begunska kriza" $v$ Sloveniji in Avstriji (J5-9445), ki ju financira ARRS, Javna agencija za raziskovalno dejaunost.

DOI: $10.51936 /$ tip. $58.2 .785-805$ 
je pandemija v letu 2020 zaustavila migracije za okvirno 27\% (IOMa: 25. marec 2021) $)^{1}$.

Ta podatek izraža mnogotere družbene realnosti: da so migranti ujeti v situacijah, v katerih so njihove možnosti gibanja omejene in so omejitve glede prehajanja mej restriktivne, da ima slednje odločujoč vpliv na možnosti in nemožnosti njihovega dela ter, nadalje, da pogosto nimajo dostopa do delovne in socialne varnosti in tudi da morebiti ne bodo mogli pravočasno urejati svojega pravnega statusa (ibid.). Zaradi pandemije so eskalirale strukturne neenakosti tako med državljani kot tudi med migrantsko populacijo. Za migrante to pomeni večje tveganje družbene izključenosti, za družbe pa kompleksno zahtevo po ohranjanju družbene kohezije in solidarnosti, temelječe na varovanju človekovih pravic migrantskih delavcev napram populističnim politikam zavračanja (več: Pajnik in Sauer (ur)., 2017; Pajnik (ur.), 2015).

V članku analiziramo družbenoekonomske učinke pandemije na migracije, pri čemer se osredotočamo na dve raziskovalni vprašanji: 1.) Kako sta Covid-19 in mobilnost, torej zaustavitev družbenega življenja, vplivala na migracije in migrantsko delo v obdobju pandemije? Zanima nas preplet področja trga dela in zaposlovanja z družbeno (ne)enakostjo in tveganji, 786 ki jih prinašajo družbene krize. 2.) In nadalje, kakšni so specifični družbenoekonomski vplivi, ki uokvirjajo migracije v času zdravstvene krize in so konkretno povezani z izpadom dohodkov iz dela? V okviru obeh vprašanj bomo naslovili tudi vidik zaostrene populistične in diskriminatorne retorike do tujcev, ki jih čas pandemije dodatno poglablja.

Namen članka je - vsaj preliminarno - odgovoriti na vprašanje o vlogi migrantskega dela med pandemijo, pa tudi obstojnosti in možnostih preživetja migrantskih ekonomij (zlasti podjetništva in trgovine) v času globalnega zapiranja ekonomij in omejene čezmejne mobilnosti. Pri tem je pomembno vedeti, da so številni sektorji povsem odvisni od delovne sile, ki je domači trgi dela preprosto nimajo. Metodologija v članku temelji na kritični analizi najnovejših podatkov - večji del iz let 2020, 2021 - ki jih zbirajo globalni akterji in upravljalci mobilnosti, migracij, človeških virov in finančnih tokov in jih uporabljamo kot relevantno dodatno literaturo ob aktualnih znanstvenih analizah.

Migrantsko delo v času zapiranja ekonomij in splošnega zaustavljanja družbenega življenja najprej deli usodo nacionalnih ekonomij, zatem pa tudi globalne. A gre tudi za specifičnosti in nenaključno ambivalentnost, ki jo zazna sociološka terenska analiza: izrisuje se namreč spoznanje, da so migranti delali, medtem ko je srednji razred poučeval, administriral, vodil, opravljal ... delovne procese od doma. Tezo, da so migranti ostali na delovnih

1 IOM: Covid-19 and Mobility, 25. 3. 2021. 
mestih, da smo »drugi« lahko delali od doma, bomo kritično pretresli skozi tradicionalne sektorje migrantskega dela. Nedvomno so to tista področja, kjer je potrebna fizična prisotnost, npr. gradbeništvo, transport, kmetijstvo, ki ne omogočajo virtualnih oblik. $\mathrm{V}$ tem oziru poudarjamo velik pomen migrantskega dela za relativno nemoteno funkcioniranje družbe med največjo zdravstveno krizo; odvisnost nacionalnih ekonomij od migrantskega dela je stalnica, ki jo je pandemija še zaostrila in tudi dodatno razkrila.

\section{Izpogajana (ne)mobilnost $\mathbf{v}$ času pandemije}

Meje pandemije so postale tudi meje mobilnosti, s korona krizo pa je sedentarnost postala nov imperativ globalne (ne)mobilnosti. Do nedavnega nepredstavljiv zastoj mobilnosti, ki se je zgodil na globalni ravni, je skozi gesli \#ostanidoma in \#delajoddoma kot temeljnima napotiloma javnih politik pri obvladovanju zdravstvene krize prinesel zapiranja meja nacionalnih držav in številnih manjših teritorialnih entitet, s tem pa je prišlo do povsem novega tipa družbenega dogovora o režimu mobilnosti. Izpogajana (ne) mobilnost $\mathrm{v}$ družbah ni bila povsem nekonfliktna, a je bila zaradi podobnih ukrepov v vseh državah sprejeta z relativno majhnimi družbenimi upori. ${ }^{2}$ A aktualni zastoj mobilnosti seveda niti ni prvi niti ne prinaša prav izvirnih ukrepov omejevanja virusa $v$ smeri dobrobiti javnega zdravja.

Že kratek zgodovinski uvid pove, da so predstave o zdravju in kužnosti v povezavi z mobilnostjo ljudi neločljivo povezane (Greenaway in Gushulak, 2017), kar je vidno zlasti skozi uveljavljene in do danes ohranjene prakse preverjanja in zdravstvenega testiranja ljudi, ki prihajajo od zunaj. V prejšnji analizi s soavtorico (Zavratnik in Cukut Krilić, 2021) pokaževa, da zgodnji zapisi o povezovanju izbruhov nalezljivih bolezni in potovanj ljudi obstajajo že v antični Grčiji in Rimu; in nadalje, da so karanteno kot prakso za zajezitev okužb, ki so takrat od zunaj prihajale zlasti z ladij, uveljavili v 14. stoletju, ko je prišlo do izbruha bubonske kuge. $\mathrm{V}$ tem obdobju je bila sicer odreditev karantene bolj vezana na potovanja zaradi trgovinske dejavnosti kot pa na migracije, kakršne imamo v mislih v modernih, globaliziranih družbah (Greenaway in Gushulak, 2017). Četudi so bile bolezni pogosto prepoznane kot del mednarodnih potovanj in procesov kolonizacije in grajenja imperijev, pa so bile migracije $v$ kasnejših obdobjih (na primer Ircev v ZDA v prvi

2 Demonstracije zaradi omejitev gibanja prebivalstva in ukrepov za zaustavljanje in izoliranje virusa so se pojavile nekaj časa po prvih šokih in številnih smrtnih žrtvah, ki smo jim bili priča v največjih žariščih krize na Kitajskem in v Evropi (predvsem v Italiji). Projektni upori, sprva predvsem proti nošenju mask, potem proti vsem ukrepom, do aktualnih proti cepljenju, potekajo po urbanih središčih širom sveta in združujejo heteregone skupine in posameznike, ki problematizirajo poseganje v osebne svoboščine (npr. pravico do gibanja, obvezno nošenje mask ipd.) ter stavijo na neznanstvene razlage oziroma znanosti odvzemajo status kvalificirane razlagalke družbene realnosti (Zavratnik, 2021a). 
polovici devetnajstega stoletja, ki naj bi v ZDA prinašali kolero) pomemben dejavnik utrjevanja praks karantene kot enega od načinov varovanja javnega zdravja prebivalstva. V drugi polovici dvajsetega stoletja je prebivalstvo postajalo vedno bolj mobilno in povezano, $\mathrm{k}$ čemur so pripomogli razmah letalskega prometa in mednarodna potovanja, slednja pa so bolj kot migracije same postala ključni označevalec in domnevni razlog za globalno širjenje epidemij različnih nalezljivih bolezni, na primer virusov SARS, zika itn. (ibid.). Nekatere države, na primer Nemčija, Francija in Združeno kraljestvo, še danes v duhu dediščine devetnajstega stoletja uporabljajo za oceno zdravstvenih tveganj pri mednarodnih migracijah ukrepe, kot je npr. presejanje migrantov za tuberkulozo, na podlagi katerih lahko zavrnejo vstop ali odredijo karanteno (Taylor v Dingwall et al., 2013).

Takšne ukrepe $\mathrm{v}$ širšem kontekstu štejemo za del vladovanja in nadzora nad migracijami (Scott et al., 2014). Seveda je bil nadzor nad gibanjem prebivalstva že pred epidemijo ena ključnih značilnost migracijskih politik, pri čemer so se države opirale na sodobne tehnologije bionadzora, kot so droni in aplikacije za sledenje. S pandemijo se je vloga orodij za sledenje gibanja ljudi še okrepila in postala tudi orodje za sledenje gibanja virusa (McDonnell, 2020; Molnar, 2020), kar kaže na nadaljnjo sekuritizacijo ne samo migracij, temveč tudi zdravja in bolezni. Kot poudarja Emily McDonnell (2020), so milijoni ljudi že pred epidemijo izkušali učinke globalnega režima nemobilnosti. Pri tem tudi "percepcije javnosti sledijo javnim politikam, ki migracije klasificirajo skozi ustaljene kategorije zaželenih vs. nezaželenih ter posledično legitimnih vs. nelegitimnih migrantov, $s$ tem pa se v javnih politikah definirane dihotomije utrjujejo v percepcijah javnosti« (Zavratnik et al., 2017). Vloga klasifikacije $\mathrm{v}$ praksah discipliniranja, ki zadevajo migranta kot Drugega, se na izrazit način kaže tudi v nadzoru migrantov kot možnega izvora okužb in bolezni, s čimer se temi migracij in javnega zdravja neločljivo povežeta. Napetosti in strahovi, ki so v sodobnih družbah prisotni glede nacionalnih meja, kot tudi prakse, ki naj bi zmanjševale tveganje njihovega prehoda, se namreč neposredno artikulirajo v strahovih pred mobilnimi telesi migrantov (Scott et al., 2014).

Migranti $\mathrm{v}$ pandemiji niso ranljivi le zaradi statusa migranta, temveč njihovo ranljivost lociramo na presečišču razreda, rase, spola in družbenega statusa: srečujejo se s specifičnimi ovirami, zaradi katerih imajo slabši dostop do zdravstvene oskrbe, spregledani so v programih zagotavljanja blaginje, bojijo se stigmatizacije, nekateri tudi aretacij in deportacij (Guadagno, 2020). Pandemija je torej pokazala, da obstoječe zdravstvene in druge neenakosti pomembno povečujejo ranljivosti za bolezen in krepijo neenake družbene strukture (Pertek et al., 2020). Razredna delitev je tako rekoč vpisana v človeška telesa in se odraža v krajši življenjski dobi in slabšem zdravstvenem stanju revnejših, revni in manj zdravi pa so bolj 
podvrženi zapletom pri okužbi z virusom Covid-19. Kot ugotavlja Ploštajner (2021), podatki iz ZDA potrjujejo, da se razredna in rasna razmerja močno prekrivajo. Podobno ugotavljajo tudi raziskovalci iz Indije, ki v uvodu zbornika Meje epidemije (2020) poudarijo, da epidemija, ukrepi za nadzorovanje širjenja virusa in geopolitika še nikoli niso bili tako zelo povezani, hkrati pa je pandemija razkrila desetletja slabih politik na področju zdravstva (v: Cukut Krilić, 21. maj, 2020). ${ }^{3}$ V družboslovju nas zanimajo epidemije kot vir negotovosti, nestabilnosti, družbenih kriz, torej predvsem kako družbe identificirajo nalezljive bolezni, kako se nanje odzivajo in kakšne so njihove širše družbene implikacije (Dingwall et al., 2013). V pričujočem tekstu pa nas zanima le ožji vidik posledic za migrantske delavce, ki so zaradi zaustavljanja družbenega življenja, vključno z gospodarstvom, v novih tveganih ali vsaj nepredvidljivih situacijah. Pri tem so velike razlike za tveganja in (presečne) ranljivosti med tistimi, ki lahko delajo od doma, in tistimi, ki te varne možnosti nimajo, nadalje, med tistimi, ki delajo v varnih oblikah zaposlitve, in vsemi drugimi prekarci. Ali prevedeno v drug vidik sociološke konceptualizacije: virus je pomemben dejavnik zaostrovanja družbenih neenakosti, pri čemer je med ključnimi strukturnimi deskriptorji družbeni razred.

\section{Vpliv pandemije na položaj migrantov v gospodarstvu}

Migrantsko delo je konstitutiven in nenadomestljiv del sodobnih zahodnih ekonomij. Evropska povojna gospodarstva so namreč utemeljena na različnih oblikah dela gostujočih delavcev. Ubesedeno s konceptom Gastarbeiter, ki ga je iznašla nemška migracijska politika in je pomemben del zagona Nemčije v 50. in 60. letih kot tudi širšega evropskega industrijskega buma, obnove in vzpona izčrpane in razrušene Evrope, imajo migracije konstitutivno mesto v zgodbi o uspehu zahodnih ekonomij (Bade, 2005; De Haas, Castles in Miller, 2014; Goldin, Cameron in Balarajan, 2012; Mežnarić, 1986). Povojni evropski prostor je prav z delovnimi migracijami postal bolj etnično, kulturno, versko raznolik, pa tudi vse bolj ekonomsko uspešen. Teza, da je trg dela v sodobnih družbah liberalnega zahoda ključno odvisen od migrantskega dela, je tako rekoč postulat modernih ekonomskih in razvojnih politik ${ }^{4}$.

3 Dostopno prek https://virusnimameja.com/2020/05/21/recenzija-zbornika-meje-epidemije-covid-19-in-migrantski-delavci-in-delavke/, 21. 5. 2021.

4 Slednje v tem delu Evrope kažejo tudi izsledki raziskovalnega projekta SEEMIG, ki potrjuje nujnost migrantskih delavcev za nemoteno delovanje zahodnoevropskega trga, od industrije in kmetijstva do zagotavljanja storitvenih dejavnosti (Managing Migration and Its Effects in South-East Europe - Transnational Actions Towards Evidence Based Strategies, SEEMIG, 2012-2014). 


\section{Širši kontekst: migrantsko delo $v$ času zapiranja ekonomij}

Vplivu pandemije na gospodarstva posameznih držav, vključno z globalnimi in mikro vplivi na lokalne skupnosti, je bila posvečena enormna raziskovalna pozornost od samega začetka pandemije. Negativne učinke, ki bodo na področju svetovnega gospodarstva, zaposlovanja in širšega družbenega življenja najverjetneje vidni še dobršno število let po krizi, v poročilih redno spremljajo in analizirajo, denimo, Mednarodna organizacija za delo (ILO, 2021) $)^{5}$, Svetovna banka $(2020)^{6}$ in številne raziskovalne ter ekspertne organizacije. Vplivi pandemije in posledično zastoji ter zapiranja gospodarstev imajo kompleksne in presečne posledice za družbenoekonomsko življenje, med njimi se najpogosteje navajajo izguba dohodka in visoka brezposelnost prebivalstva ter krčenje ali celo propad specifičnih ekonomskih dejavnosti. Številne agencije Združenih narodov, med njimi UNHCR, tudi IOM ter Svetovna banka, so zagnali raznotere programe in projekte za omilitev posledic pustošenja največje družbene krize med najranljivejšimi prebivalci sveta, vključno z migranti. ${ }^{7}$ Odgovor na vprašanje, kako uspešni bodo v boju s posledicami zdravstvene krize, pa bo mogoče izmeriti šele v evalvacijah post-pandemičnega obdobja. Seveda je pričakovano, da vse omenjene spremembe beležimo tudi v ožji perspektivi, to je v ekonomski realnosti mednarodnih migracij, v primerih geografskih velikanov, npr. Indije in Kitajske, pa tudi pri notranjih migracijah.

$\mathrm{V}$ analizi širšega odnosa med migracijami in gospodarstvom, zlasti z vidika evalvacije gospodarskega prispevka migrantov, zajemamo s pojmom migranti vse diferencirane statuse ljudi, ki živijo zunaj države bivanja, to je delovne migrante, študente, podjetnike, družinske člane migrantov, dalj časa izseljene ljudi oziroma diasporo kot tudi njihove povezave z izvornimi okolji. Obstajajo namreč številne oblike, skozi katere migranti in diaspora prispevajo tako skupnostim v izvornih državah kot tudi v novih družbah. V tej perspektivi sledimo metodologiji, ki jo je začrtal IOM (Issue Brief, 15. junij 2021); osredini se na tri oblike neposrednih vplivov na gospodarstvo: denarna nakazila, migrantsko delo na trgu zaposlovanja in podjetništvo ter trgovino (IOM, 2021). Svetovno migracijsko poročilo za leto 2020 pa med vidne ekonomske prispevke migrantov in diaspor navaja, denimo, tudi prenos veščin in tehnologij, investicije v podjetja, portfolio in nepremičninski trg (World Migration

5 ILO: World Employment and Social Outlook. Trends 2021 International Labour Office, Geneva.

6 The World Bank Annual Report 2020a: Supporting Contries in Unprecedented Times.

7 Na primer multilateralni program švicarske in britanske vlade, ki skupaj z Združenimi narodi in partnerji iz industrije in civilne družbe stremi $k$ vzdrževanju toka denarnih nakazil, tj. Stocktalking Report, 2021; nadalje programi Svetovne banke v sodelovanju z različnimi agencijami Združenih narodov, zlasti WHO in UNHCR, specializirani programi IOM, npr. Strategic response and recovery plan Covid19, January - December 2021, 2021b) ipd. 
Report, 2020a). V širši sociološki perspektivi obravnavamo sodobne migracijske poti v kontekstu transnacionalnih omrežij in poti, ki so vzpostavljene med izvornimi in ciljnimi državami ter skupnostmi in med njimi potekajo živahne izmenjave: finančne, trgovske, delovne, kulturne. Prav tako upoštevamo tranzitne prostore, kjer so se migracijske poti med pandemijo tudi zaustavljale in spreminjale; problematizacija je nazorna na primeru balkanske poti, na kateri je prišlo do zaustavitev in tudi do povsem nelegalnih praks zavračanja na mejah in omejevanja možnosti dostopa do azila (Zavratnik in Cukut Krilić, 2021; Cukut Krilić in Zafošnik, 2021; Zafošnik, 2021).

O položaju migrantskih delavcev je poveden podatek, da je v času pandemije okoli $75 \%$ svetovnih migrantov delalo v državah, kjer je prišlo do treh četrtin vseh okužb s Covidom-19. Poročilo "Stocktalking" z naslovom "Nakazila v krizi: kako jih ohranjati v teku« (junij 2021) pokaže, da kar $90 \%$ vseh denarnih nakazil na svetu prihaja iz teh držav, kar ima posledično velik vpliv na denarne tokove in življenjski standard številnih ljudi in gospodinjstev. Analiza IOM (Guadagno, 2020) pokaže identičen trend: največja koncentracija migrantov je v razvitih državah industrijskega zahoda - Švica, Belgija, Nemčija, Nizozemska, Združeno kraljestvo, Francija, Španija, ZDA -, kjer delež migrantske populacije znaša med $10 \%$ in $15 \%$, v nekaterih primerih tudi čez $20 \%$.

Poleg tega so območja, ki so bila najboljprizadeta v mnogih od teh držav, na primer regija Lombardija v Italiji, New York, madridsko in pariško metropolitansko območje v Združenih državah Amerike, Španija in Francija ter območje Ženeve/Vauda $v$ Švici, središča mednarodnih gospodarskih in trgovskih mrež ter političnega in kulturnega življenja in imajo višji deleže migrantov od povprečja. (Guadagno, 2020: 3)

Posledično je naraščanje števila okužb v nekaterih najbolj pomembnih ciljnih državah za migrante pomenilo izgubo možnosti stabilnega zaslužka in avtonomnega življenja; tako preživljanja sebe kot družin v ciljnih državah ali tistih, ki so odvisni od njihovih zaslužkov v izvornih državah. V širšem kontekstu je pomembno povezovanje dveh družbenih vidikov: „Vpliv pandemije Covida-19 na migrante in njihovo trajno sposobnost, da delujejo kot ekonomski akterji, je povezan tako z zdravstveno kot z ekonomsko razsežnostjo krize. Na ekonomski prispevek migrantov pa bo pomembno vplivala oblika in trajanje trenutne svetovne recesije (International Organization for Migration - IOM, 2020c:1). O slednji razberemo nekaj ključnih poudarkov iz poročila Mednarodnega denarnega sklada, ki ocenjuje, da se je svetovno gospodarstvo leta 2020 skrčilo za 3,3 odstotka glede na pred pandemijsko obdobje, medtem ko naj bi leta 2021 svetovna rast znašala 6 odstotkov (International Monetary Fund - IMF, 2021). 
V prvem obdobju pandemije je kazalo, da so takojšnji ekonomski učinki enaki tako za migrante kot za državljane: številne prekinitve ekonomskih aktivnosti so terjale izpad dohodka in večale brezposelnost. A so bili ti učinki pri migrantskih delavcih še bolj zaznani. Podatki, da so bili migranti med prvimi delavci, ki so bili odpuščeni, prihajajo z vseh strani. Osrednji ameriški inštitut na področju javnih migracijskih politik, washingtonski Migration Policy Institute, poroča, da so bili migranti nesorazmerno prizadeti zaradi gospodarske krize kot posledice pandemije in da se slednje kaže tako na ravni ZDA kot $\mathrm{v}$ večini največjih ciljnih držav priseljevanja (MPI, 2021: 3). Pomembno je upoštevati dejstvo, da so številni migranti zaposleni $\mathrm{v}$ neformalnem sektorju, pogosto brez ustreznih delovnih pogodb in zavarovanja ter $\mathrm{v}$ popolnoma prekarnih zaposlitvah, pogosto z omejenim dostopom do socialne in zaposlitvene varnosti, zaradi česar je ekonomski šok ob pandemiji za to populacijo toliko večji. Zato migranti nedvomno predstavljajo - četudi gre za izjemno diverzificirano družbeno kategorijo - ranljivo družbeno populacijo, ki je zaradi strukturnih značilnosti trga dela v obdobju pandemije in zaradi pogosto omejenega dostopa do javnega zdravstva plačala visok davek: številni so izgubili dohodek, službe, zmožnost preživljanja sebe in družin, mnogi med njimi tudi zdravje (Guadagno, 2020).

Raziskovalci razmer v Indiji (Calcutta Research Group, 2020) kot tudi študije na Kitajskem (Bofulin, 2020) poročajo o množicah notranjih migrantov, ki so se v teh velikanskih državah vračale iz razvitejših urbanih področij v domače ruralne kraje, kamor so prišli še bolj revni, kot so od tam odšli, hkrati pa jih je pogosto pričakalo odkrito nasprotovanje domačega prebivalstva: bili so namreč potencialni nosilci kužnosti. Zato so pogosta poročila o zavračanjih, verbalnih in celo fizičnih napadih. V začetku 2020 so Združeni narodi opozorili na "cunami sovraštva in ksenofobije «, ${ }^{8}$ ki se je globalno razvnel kot posledica strahu in dezinformacij ob virusu in globalni zdravstveni krizi, ki jo je povzročil. Številni migranti azijskega izvora so bili neposredne tarče na začetku širjenja epidemije, v kasnejši fazi je diskriminacijske prakse zaznati proti ljudem migrantskega izvora na različnih področjih vsakdanjega življenja širom sveta, npr. pri najemanju stanovanj, v šoli, na javnem prevozu itd.

O nevarnosti stigmatizacije in diskriminacije ljudi na migracijskih poteh, ki se v daljšem obdobju zaustavitve družbenega življenja in posledično konfliktov zaradi negativnih ekonomskih posledic utegne v družbi še dodatno krepiti, sprejemajo pomembne politične izjave in svarijo številni akterji: na globalni ravni že omenjeni IOM in UNHCR, ${ }^{9}$ na ravni Evropske unije pa zlasti Agencija Evropske unije za temeljne pravice (FRA) in tako rekoč celoten

8 Human right Watch: Covid-19 Fuelling Anti-Asian Racism and Xenophobia Worldwide, UN Press Note, 12. Maj 2020.

9 Glej npr.: IOM: Countering xenophobia and stigma to foster social cohesion in the Covid-19 response and recovery, Issue Brief, 14. July 2020b; Blog UNHCR, ki prinaša informacije o aktualni situaciji s terena, 
korpus nevladnih in aktivističnih kolektivov, ki delujejo na področju varovanja človekovih pravic marginaliziranih posameznikov in družbenih skupin. Ti so prisotni na terenu, predvsem ob zunanjih mejah EU in uveljavljenih migracijskih poteh in koridorjih ter $\mathrm{v}$ urbanih periferijah, kjer je največ migrantov in beguncev.

Manko podatkov ta čas še onemogoča natančnejše odgovore na kompleksno vprašanje ekonomskih posledic za položaj migrantskih delavcev po letu/letih pandemije, zlasti na ravni mikro analize, ki bo lahko reflektirala ekonomske in druge življenjske okoliščine delavcev migrantov, podjetnikov in njihovih družin. Virtualne metodologije so v času zdravstvene krize sicer morale nadomestiti terensko raziskovanje, a vendarle niso zmogle nadomestiti terenske sociološke analize. Ta še kako pogreša ustaljene modele dela na terenu, ki temeljijo na osebnih stikih in intervjujih s posamezniki, fokusnimi obravnavami relevantnih družbenih skupin ipd. Kljub evidentnemu manku podatkov pa razpoložljive študije kažejo zanesljiv trend: pandemija je poglobila družbene ločnice. "Novi revni«, razred, kreiran s pandemijo, so še bolj revni in jih je več. To potrjuje tudi ocena Svetovne banke, ${ }^{10} \mathrm{ki}$ je oktobra 2020 napovedala, da bo pandemija Covida-19 v letu 2020 v skrajno revščino potisnila dodatnih 88 do 115 milijonov ljudi, medtem ko se bo njihovo skupno število v letu 2021 povzpelo na 150 milijonov; pri čemer so številčne ocene v soodvisnosti z resnostjo krčenja gospodarstva. Nadalje naj bi v letu 2020 - izhajajoč iz dveletnega Poročila o revščini in deljeni blaginji - skrajna revščina, opredeljena kot življenje z manj kot 1,90 dolarja na dan, verjetno prizadela med $9,1 \%$ in 9,4\% svetovnega prebivalstva, kar bi pomenilo nazadovanje na stopnjo v letu 2017. V kolikor ne bi prišlo do pandemije, ocenjuje Svetovna banka v istem poročilu, bi se stopnja revščine leta 2020 znižala na 7,9\%. Jasno je, da migranti in begunci v velikanskem deležu sodijo med tiste, pri katerih je tveganje, da postanejo "pandemijsko novi revni«, najbolj prisotno.

\section{Specifični družbenoekonomski učinki migracij v času pandemije}

\section{Denarna nakazila}

Denarni tokovi (remittances) so eden osrednjih kriterijev, s pomočjo katerih ocenjujemo ekonomske učinke migrantskega dela na podlagi transakcij med ciljnimi in izvornimi državami. Nakazila v domača okolja imajo za lokalne skupnosti v izvornih državah pomembne razvojne učinke; ker

\footnotetext{
dostopno prek https://www.unhcr.org/news/stories/2020/4/5e79e2410/live-blog-refugees-covid-19-crisis. html:query=covid-19, 14. 7. 2020.

10 Več glej: World Bank: Brief 33; Brief 34; Dostopno prek https://www.worldbank.org/en/news/press-release/2020/10/07/covid-19-to-add-as-many-as-150-million-extreme-poor-by-2021, 10. 7. 2020.
} 
neposredno znižujejo revščino in na splošno prispevajo k boljši kvaliteti življenja, so pomemben vir sredstev za preživetje ožjih družin migrantov in pogosto tudi širših sorodniških mrež (De Haas, 2005; Panda 2009; Pajnik in Bajt, 2010; Yang, 2011). V poročilu IOM (15. junij 2021) beremo oceno Združenih narodov, da se kar $\$ 75 \%$ nakazil porabi za kritje osnovnih potrebščin, kot so hrana, šolnine, zdravstveni stroški in stanovanja, medtem ko na ravni celotnega gospodarstva $\mathrm{v}$ več državah denarna nakazila predstavljajo pomemben del nacionalnega BDP in pomagajo pri oblikovanju rezerv (2021c:2). Leta 2020 so globalni tokovi migrantskih nakazil geografsko precej variirali, tudi glede na nastajanje novih migracijskih koridorjev, nadalje glede na razlike $\mathrm{v}$ menjalnih tečajih in predvsem glede na splošne ekonomske in kulturne dejavnike. V začetku leta 2020 je bilo pri nakazilih opaziti trend upadanja zaradi zapiranja držav in ukrepov omejevanja, prav tako je vzrok tudi v brezposelnosti, ki je upočasnila gospodarstva, še poročajo pri IOM.

Vendar pa so analitiki sočasno zaznali tudi nasproten trend, namreč v določenih koridorjih in v določenih časovnih intervalih so se denarni tokovi povečali. Tak primer so nakazila v Kolumbijo, Salvador in Dominikansko republiko, kjer je prišlo do pozitivnega letnega porasta v obdobju od junija do septembra 2020, ki je sledil poprejšnjemu upadu v aprilu in maju 2020 794 (IOM, 2021c). Zagotovo je najbolj zanimiv podatek, da so se denarni tokovi migrantov do konca leta 2020 navkljub globalnemu zaustavljanju ekonomij in tako rekoč izklopu družbenega življenja izkazali za odporne na družbene krize. Podatki, ki kažejo stabilnost v kriznih časih, namreč sporočajo, da je bil pri nakazilih zabeležen manjši padec, kot je bil predviden, nižji tudi od upada v obdobju svetovne finančne krize leta 2009 (ibid.). IOM nadalje povzema podatke Svetovne banke (maj 2021), da so bili uradno zabeleženi tokovi nakazil v države z nizkim in srednjim dohodkom leta 2020 le 1,6 odstotka pod ravnijo iz leta 2019, prav tako so tokovi nakazil v tem obdobju presegali neposredne tuje naložbe in uradno razvojno pomoč

Po ocenah ekspertov pri IOM (2021c: 3) so imeli zaustavitev družb med pandemijo, ukrepi karantene ter prostorskega distanciranja v letu 2020 dvoje ključnih učinkov za organizacijo denarnih nakazil migrantskih delavcev: 1. omejitve osebnega in maloprodajnega poslovanja izvajalcev denarnih prenosov, ki predstavljajo 60 odstotkov nakazil, in 2. naraščajoč trend k digitalizaciji nakazil in posledično večja formalizacija tokov nakazil (ibid.). Kljub temu tehničnemu vidiku ovir pričujoči podatki kažejo precej jasno sliko, ki govori v prid neprekinjene ekonomske aktivnosti migrantov. Kar smo opazovali v lokalnih okoljih, vključno s Slovenijo, se na globalni ravni pokaže prav na točki obstojnosti denarnih tokov in prinaša jasno sporočilo: migranti so med krizo delali.

Položaj migrantskih delavcev v obdobju po pandemiji pa bo odvisen od tega, kako hitro se bodo lahko vrnili na prejšnje zaposlitve in kakšne 
politike bodo pri tem ubrale države. A dejstvo je: ker so denarna nakazila v globalnem oziru tako pomemben gradnik številnih gospodarstev in kažejo na globalno prepletenost ter soodvisnost, gre s precejšnjo gotovostjo predvidevati veliko naklonjenost mednarodne skupnosti za hitro obnovo stanja na trgu dela, kakršno je bilo pred pandemijo. Takšno napoved bi lahko ovrgla le dalj časa trajajoča zdravstvena kriza, kar pa je zaradi (relativne) dostopnosti cepiva manj verjetno.

\section{Delouna sila}

Po podatkih Mednarodne organizacije za delo (ILO) so na velik delež, približno 164 milijonov migrantskih delavcev, ki so vključeni v mednarodni trg dela, vplivali omejevalni ukrepi zaradi Covida-19, kar je povzročilo stagniranje ali upadanje udeležbe migrantov na trgu dela. ${ }^{11}$ Spomnimo ponovno na ključen podatek, da je glavnina migrantskih delavcev vključena na trg dela v državah z velikimi izbruhi pandemije Covida-19. Posledično se je ILO (april 2020) odzvala na vprašanje zaščite migrantskih delavcev med pandemijo s priporočili za oblikovalce politik, ${ }^{12} \mathrm{v}$ katerih apelira na zagotavljanje ustreznih ukrepov na področju javnega zdravja in ekonomske politike, a tudi širšega družbenega konteksta. Priporočila gredo z roko v roki z Združenimi narodi, ki opozarjajo, da virus ne diskriminira, prav tako se nanj ne smemo diskriminacijsko odzvati. V eni pogostih izjav opozarjajo na negotov položaj in ranljivost migrantov. »Še posebej pomembno je, da si vse oblasti po najboljših močeh prizadevajo za soočanje s ksenofobijo, tudi tam, kjer so migranti in drugi izpostavljeni diskriminaciji ali nasilju, ki je povezano z nastankom in širjenjem pandemije. Covid-19 ne diskriminira, in če naj bomo uspešni, tudi naš odziv ne sme. ${ }^{13}$ Tovrstni odzivi so v boju proti diskriminaciji migrantskih delavcev, beguncev in na splošno tujcev v času poglobljene družbene krize zelo pomembno sporočilo za vse nivoje javnih politik: države, lokalne skupnosti in regije, za same migrante in za državljane ciljnih družb.

Strogi ukrepi med zaustavitvijo družb so močno vplivali na sektorje z nizkimi plačami in nižje kvalificirano delovno silo. To pa so tudi panoge z visokim deležem migrantskih delavcev - transport, turizem, kmetijstvo, gradbeništvo in zdravstvo.

${ }^{11}$ ILO Monitor: COVID-19 and the world of work. Third edition Updated estimates and analysis 29 April 2020.

${ }^{12}$ ILO: Protecting migrant workers during the COVID-19 pandemic Recommendations for Policymakers and Constituents.

${ }^{13}$ UN Human Rights Office: COVID-19 does not discriminate; nor should our response. 20 March 2020. 
Zaustavljena mobilnost in transport. Migration Policy Institute in IOM $\mathrm{v}$ analizi »Covid-19 in položaj svetovne mobilnosti ${ }^{14}$ poročata o dramatično zmanjšanem čezmejnem gibanju v letu 2020, zaustavitev prehajanja meja pa je postala mejnik za človeško mobilnost vseh vrst. Pandemija je zdesetkala turizem in poslovna potovanja, vplivala je na (ne)mobilnost delovne sile in omejila delovanje transporta, kar je vplivalo na čezmejne poti študentov, delavcev, razseljenih družin itd. Poročilo ugotavlja, da so vlade in regionalne oblasti v transportnem sektorju do konca marca 2021 izdale ali podaljšale 43.300 uredb oz. odlokov v zvezi s potovanji in, nadalje, da je za vse države, ozemlja in območja po vsem svetu veljalo vsaj 70 prepovedi potovanj. Tak režim je imel neposreden vpliv na sektor transporta, četudi so bile meje za dobrine pod različnimi režimi prehajanja, torej pogojno, ves čas odprte.

Turizem. V okviru Združenih narodov delujoča Svetovna turistična organizacija (UNWTO) poroča o drastičnem upadu. Število mednarodnih prihodov turistov se je med januarjem in decembrom 2020 zmanjšalo za približno milijardo ali za 73\%. V prvem četrtletju leta 2021 pa Svetovni turistični barometer UNWTO kaže na 84-odstotni upad. ${ }^{15}$ Skupno poročilo Konference Združenih narodov o trgovini in razvoju (UNCTAD) in Svetovne turistične organizacije iz junija $2021^{16}$ pa prinaša podatek, da bi svetovno gospodar796 stvo zaradi globalnega zloma turističnega sektorja kot posledice Covida-19 lahko izgubilo pomemben delež svetovnega BDP za leti 2020 in 2021. Največje izgube so nastale v državah v razvoju, kjer je bil zabeležen najvišji upad turističnih obiskov v letu 2020, med 60\% in $80 \%$. Okrevanje turističnega sektorja pa agencije povezujejo predvsem z globalno uspešnostjo cepljenja, pri čemer ne smejo izostati revnejše države oziroma sta - kot poudarijo - ključnega pomena dostop in »cepilna pravičnost« (ibid.).

Kmetijstvo. V kmetijskem sektorju so omejitve gibanja povzročile primanjkljaj približno milijon sezonskih kmetijskih delavcev samo v Evropski uniji, poroča IOM na podlagi podatkov Agencije ZN za hrano in kmetijstvo (IOM, 2021c:3). Agencija ZN za hrano in kmetijstvo je v odzivu aprila $2020^{17}$ poudarila pomembno vlogo migrantov v kmetijsko-živilskih sistemih zahodnih družb. Eno temeljnih sporočil je, da bodo ukrepi, ki vplivajo na gibanje ljudi (notranje in mednarodno), in posledično pomanjkanje delovne sile vplivali na obstoječe prehranske verige v kmetijstvu, posledično pa na razpoložljivost hrane in globalne tržne cene. Prav tako opozarjajo, da velik delež migrantov dela v neformalnih delovnih razmerah ali priložnostnih

${ }^{14}$ MPI in IOM: Covid-19 and the State of Global Mobility, 20. 3. 2020.

15 Covid-19 and Tourism, 2021, https://unctad.org/system/files/official-document/ditcinf2021d3. en_o.pdf.

16 UNWTO (2021): Global economy could lose over \$4 trillion due to COVID-19 impact on tourism, 30 June 2021

17 UN Food and Agriculture Organisation: Migrant workers and the COVID Pandemic, 7 April 2020. 
dogovorih, zaradi česar so nezaščiteni, ranljivi za izkoriščanje, revščino in prehransko negotovost ter pogosto brez dostopa do zdravstvenega varstva in socialne zaščite. Izpostavljajo, da morajo biti ukrepi usmerjeni k zaščiti delavcev na delovnem mestu, razširitvi začasnih delovnih dovoljenj in zagotavljanju varne mobilnosti znotraj držav in med njimi. Vsi migranti bi morali imeti dostop do zdravstvene in socialne zaščite, ne glede na njihov migracijski ali delovni status (ibid.). Primanjkljaj migrantskih delavcev na poljih Zahodne Evrope so pokazala številna poročila in raziskave, ki kažejo velike motnje in zastoje pri pobiranju kmetijskih pridelkov, temu nadalje sledijo izgube pri predelavi in distribuciji in se $\mathrm{v}$ končni fazi kot primanjkljaj pokažejo na krožniku potrošnika (več: Cukut Krilić in Zavratnik, 2021).

Gradbeništvo. Gradbeni sektor je eden tistih, ki tradicionalno zaposluje migrantske delavce, kar kažejo podatki tako za EU kot denimo tudi za Bližnji vzhod (IOM, 2021c:3). V Sloveniji so gradbišča ostala odprta, in četudi so terenske raziskave $\mathrm{v}$ preliminarni fazi, podatki kažejo na zgolj kratko prekinitev gradbenih del, ki je bila zelo hitro znova vzpostavljena. Podatki ZRSZ ${ }^{18}$ pa so povedni predvsem z vidika, da $v$ letu 2020 ni velikega upada $v$ številu izdanih delovnih dovoljenj tujcem iz tretjih držav v primerjavi s prejšnjima dvema letoma (2018 - 18.049 izdanih dovoljenj; 2019 - 17.030; 2020 - 15.636). Prav tako prvo polletje 2021 kaže prej trend višanja kot upad števila delovnih dovoljenj, saj je bilo v prvih šestih mesecih bilo izdanih prek 10.000 dovoljenj. Dosedanje študije zaposlovanja migrantov v Sloveniji pa kažejo, da jih je večina zaposlena prav v gradbeništvu (Zavratnik in Cukut Krilić, 2020; Pajnik, Bajt, Herič, 2010; Zavratnik Zimic, 2004).

Zdravstvo. Sektor javnega zdravstva je močno odvisen od migrantskih delavcev, tako zdravnikov kot drugega zdravstvenega osebja. Da so razmere v zdravstvu nedvomno pokazale odvisnost javnega zdravja od prispevka zdravstvenih delavcev migrantov, potrjuje ocena Organizacije za gospodarsko sodelovanje in razvoj, po kateri ima skoraj 20 odstotkov zdravstvenih delavcev v državah OECD migrantsko ozadje. ${ }^{19}$ Predvsem je pandemija Covida-19 do obisti razgalila, kako temeljnega pomena je razpoložljivost zadostnega števila usposobljenih in motiviranih zdravstvenih delavcev za delovanje slehernega zdravstvenega sistema, saj stabilnosti zdravstvenih sistemov obstane ali pade na točki ustreznih človeških virov. Kriza je - poleg osrednje vloge in predanega dela zdravstvenih delavcev - še bolj poudarila globoko zasidran primanjkljaj osebja in pomemben prispevek migrantskih zdravnikov in medicinskih sester ter skrbstvenega osebja med zdravstveno delovno silo v mnogih državah OECD (ibid.).

18 Podatki Zavoda Republike Slovenije za zaposlovanje, osebna korespondenca, julij 2021.

19 OECD: Contribution of migrant doctors and nurses to tacking the COVID-19 crisis in OECD countries, 13 May 2020. 
Za položaj migrantov na trgu dela je pomemben dejavnik izobrazba, ki jih večinsko opredeljuje kot nizko kvalificirano delovno silo; kot taka je na nestabilnem, pogosto prekarnem trga dela visoko ranljiva. Podobno ranljivost med nižje kvalificiranimi in neformalnimi delavci kot med krizo Covida-19 je bilo opaziti tudi med finančno krizo 2008-2009, in sicer zlasti v recesiji gradbenega sektorja, ki v ZDA zaposluje četrtino mehiških migrantov, od tega naj bi bilo več kot polovica nedokumentiranih. Zaradi ekonomske krize je takrat veliko migrantov postalo brezposelnih, zaposlenih s krajšim delovnim časom in/ali na slabo plačanih delovnih mestih, ali so se bili celo prisiljeni vrniti v Mehiko (IOM; 2021c:4).

\section{Podjetništvo in trgovina}

Raziskave kažejo, da je podjetništvo migrantov predvsem v domeni malih in srednje velikih podjetij ter mikro podjetij, nekaj pa je tudi podjetij z visoko dodano vrednostjo (IOM, 2021c; OECD, 2010). Študija »Podjetništvo in migranti« iz leta 2010 je pokazala, da je v državah OECD delež podjetnikov nekoliko višji med migranti kot med domačimi; vendar je stopnja preživetja podjetij v lasti migrantov pogosto nižja kot tistih, kateri lastniki so domačini. Slednje je tesno povezano z obstoječimi migracijskimi politikami, ki (ne) uspejo ponuditi ustrezne podlage in svetovanja za čim boljšo integracijo bodočih migrantov podjetnikov. Kot zaključuje poročilo, so migranti lahko vir ustvarjanja delovnih mest, namesto da bi z domačini tekmovali za omejeno število delovnih mest. Vendar pri tem v novi ciljni državi potrebujejo podporo pri dostopu do kapitala, učenju jezika in reševanju regulativnih ovir. Te omejitve ne veljajo nujno le za migrante z nizko izobrazbo, tudi visokokvalificirani migranti so imeli težave pri pridobivanju kapitala in razumevanju ter ustreznem odzivu na lokalne predpise (OECD, 2010: 4-5). Ugotavljamo, da se migranti v podjetništvu srečujejo s popolnoma enakimi izzivi kot lokalno prebivalstvo, le da so zanje bariere toliko večje zaradi komunikacijskega primanjkljaja: tako zaradi pomanjkljivega poznavanja jezika kot zaradi nepoznavanja administrativnega in zakonodajnega sistema, ki uokvirja podjetništvo. Različne analize primerov kažejo, poroča IOM (2021c), da je uspeh migrantskih podjetij, zlasti mikro podjetij, ključno povezan z razumevanjem in zmožnostjo slediti lokalnim regulativam; denimo, kanadski primer kaže, da je veliko migrantov začelo poslovati, se težko prilagodilo, nazadnje pa so razočarani zaradi lokalnih predpisov in davkov zaprli svoja podjetja.

OECD spodbuja države, da razmislijo o politikah, ki podpirajo lastništvo podjetij in integracijo migrantov. Migracijske politike številnih držav članic, še posebej v Evropi, so začele aktivno iskati višje izobražene migrante in specifične veščine, torej še več podjetnikov med migranti. To je prvi 
in pomemben korak k ustvarjanju uspešnejšega migrantskega podjetništva, vendar so za uspeh ključnega pomena državne institucije (2010: 25). Nadalje, analiza v ZDA (Kaufmann Enterpreneurship Indicators, 2019) je za leto 2017 pokazala, da je med migranti dvakrat večja verjetnost, da bodo ustanovili podjetja $\mathrm{v}$ primerjavi z domačini, pri čemer migranti predstavljajo skoraj 30 odstotkov vseh novih podjetij. Aktualna analiza za leto 2020 pa kaže, da je bila stopnja novih podjetnikov 0,44 odstotka med migranti, kar je bistveno višja kot med Američani (0,28 odstotka). Najvišja stopnja podjetništva je $\mathrm{v}$ tem letu zaznana med Latinskoameričani (ibid.).

Analiza IOM (2021c:4) ugotavlja, da so zaustavitve družbenega življenja zaradi Covida-19 še posebej prizadele mikro ter mala in srednja podjetja. Večina delavcev migrantov pa se - kot rečeno - nahaja prav v državah, kjer je bilo priporočeno ali zahtevano zapiranje delovnih procesov. Zaustavljanje gospodarskih sistemov je imelo takojšnje posledice za poslovanje podjetij, hkrati pa je tvorilo številne širše družbenoekonomske učinke, vključno z brezposelnostjo in tveganjem podjetij za plačilno nesposobnost. Ko so omejitve odpravljene, vnovični zagoni podjetij zahtevajo prilagoditve in posledično nove stroške. Nadalje, prekinjene so bile tudi trgovinske povezave, ki potekajo med skupnostmi v diasporah in njihovimi izvornimi državami; prekinjena je bila trgovina $s$ hrano, kulturnimi produkti, prav tako turizem. (ibid.). Za migrantske trgovce nedvomno veljajo vsi splošni šoki, ki so vplivali na širši upad trgovske dejavnosti. Zastoji so nastali zaradi mnogih prepletenih dejavnikov, od motenj oskrbovalnih verig, omejitev na mejah do sprememb cen, predvsem rasti cen surovin. Za male trgovce, ki delujejo v neformalni trgovini med sosednjimi državami, je pandemija obdobje velike negotovosti pri prihodkih, ker sta zaslužek in izpad povezana z nenehnimi valovi med odpiranjem in zapiranjem meja ter omejitvami potovanj.

\section{Sklep}

Zdravstvena kriza je v modernih družbah vzpostavila nove modele »izpogajane mobilnosti«. S pojmom označujemo družbeni dogovor o režimu mobilnosti in nemobilnosti, ki ključno definira organizacijo družbenega življenja $\mathrm{v}$ kontekstu zaostrene fizične mobilnosti. Evidentno je restrukturirana mobilnost kot ena najbolj ključnih značilnosti pandemičnega obdobja: Covid-19 je zaustavil družbeno življenje, globalno ekonomijo, mikro stike v lokalnih okoljih, mednarodne migracije itd., družbe pa soočil z novimi vidiki vprašanj solidarnosti, mobilnosti in (ne)enakosti $v$ kriznih razmerah.

$\mathrm{V}$ članku analiziramo ožje polje mobilnosti, tj. vidik mednarodnih migracij in migrantskega dela kot konstitutivnega elementa sodobnih družb oziroma ekonomij. Glavni izsledki pričujoče analize za migrantsko populacijo kažejo predvsem zaostritev in poglabljanje družbenih neenakosti glede na 
stanje pred pandemijo na eni strani ter kritično umanjkanje migrantskega dela na ravni vzdrževanja in funkcioniranja vsakdanjega življenja zahodnih družb na drugi. Tako je odgovor na prvo raziskovalno vprašanje (Kako sta Covid-19 in mobilnost, torej zaustavitev družbenega življenja, vplivala na migracije in migrantsko delo v obdobju pandemije?) potrebno kontekstualizirati v časovno-prostorskih koordinatah pred pandemijo in po njej ter $\mathrm{v}$ razmerah omejene fizične mobilnosti čez državne meje, ki kažeta migrantsko delo skozi temeljno ambivalentnost: zaustavitev migracij je skladna s pandemičnimi pravili in percipirano samoizolacijo družb »od zunaj«, a je hkrati neskladna s potrebami družbe »od znotraj«, ki mora vzdrževati temeljne funkcije in svojim prebivalcem zagotavljati javne servise, storitve in dobrine, tj. družbe, ki deluje tudi v t. i. karantenskih časih.

Da se migrantsko delo v času pandemije ni zmanjšalo, je vsaj nekoliko presenetljiv trend in najbolj pomemben odgovor na drugo raziskovalno vprašanje (Kakšni so specifični družbenoekonomski vplivi, ki uokvirjajo migracije v času zdravstvene krize in so konkretno povezani z izpadom dohodkov iz dela?). Denarna nakazila migrantov so se navkljub zapiranju ekonomij in javnega življenja $\mathrm{v}$ času pandemije pokazala za odporna na družbene krize. Migrantski delavci so med pandemijo ustvarjali tako rekoč enak obseg dohodkov kot v obdobju pred njo. Relacija do migranta kot "drugega" se v pandemiji kaže skozi zaostreno relacijo in vzpon sovražnosti, retorike in dejanj. Ponovno se srečujemo z že zaznano ambivalentnostjo: migrantom se pripisuje atribute »kulture grožnje» in med pandemijo tudi biološke kužnosti, a so hkrati percipirani tudi kot pomembni akterji vzdrževanja nekaterih ključnih ekonomskih aktivnosti, npr. kmetijstva, javnega zdravstva, trgovine.

Če na koncu zastavimo še nekoliko poenostavljeno vprašanje, ali so migrantski delavci zmagovalci ali poraženci pandemije, je odgovor dvoplasten. Prisotni so v obeh vlogah. So del globalnega prekariata, »novih revnih«, ki jih je dodatno ustvarila pandemija. In so tudi zmagovalci, ki v največji družbeni krizi sodobnega časa vzdržujejo tako rekoč nespremenjen obseg finančnih tokov v izvorna okolja. To je jasen pokazatelj, da so migranti med krizo delali kot del širšega delavskega razreda, ki je vzdrževal »odprto« družbo in omogočal temelje, da smo številni drugi lahko delali prek virtualnih platform. Seveda je relevantno vprašanje, ali so (migrantski) delavci imeli kakršnokoli drugačno možnost. Odgovor je nikalen. Globalni prekariat je nima niti onkraj aktualne krize, zato izkazana obstojnost in trdoživost migrantskega dela $\mathrm{v}$ resnici ne moreta presenetiti. Sociološka analiza namreč jasno kaže, da je virus pomemben dejavnik zaostrovanja družbenih neenakosti, pri čemer je med ključnimi strukturnimi deskriptorji prav družbeni razred. 


\section{LITERATURA}

Anderson, Bridget (2019): New directions in migration studies: towards methodological de-nationalism. Comparative Migration Studies 7 (36). Dostopno prek https:/comparativemigrationstudies.springeropen.com/track/pdf/10.1186/ s40878-019-0140-8.pdf, 30. 7. 2021.

Bade, Klaus J. (2005): Evropa v gibanju. Migracije od poznega 18. stoletja do danes, Ljubljana: Založba / ${ }^{*} \mathrm{cf}$.

Bofulin, Martina (2020): Kitajski migranti in Covid-19 - mobilnost in izključevanje med pandemijo. Dve domovini/Two Homelands 52: 95-111.

Cukut Krilić, Sanja (ur.) in Simona Zavratnik (ur.) (2021): \#Ostani doma. Migracije, begunci in Covid-19. Maribor: Kulturni center.

Cukut Krilić, Sanja (2021): Trije D-ji oskrbe s hrano. V: \#Ostani doma. Migracije, begunci in Covid-19. Maribor: Kulturni center, 39-44.

Cukut Krilić, Sanja in Anja Zafošnik (2021): Spletinar o beguncih na Balkanski poti v času Covid-19. V: \#Ostani doma. Migracije, begunci in Covid-19. Maribor: Kulturni center, 45-48.

De Haas, H. (2005): International Migration, Remittances and Development: Myths and Facts, Third World Quarterly 26 (8): 1269-1284.

De Haas, Hein, Stephen Castles in Mark J. Miller (2014): The Age of Migration. International Population Movements in the Modern World, Fifth Edition, Palgrave Macmillan.

Dingwall, Robert, Lily M. Hoffman in Karen Staniland (2013): Introduction: Why a Sociology of Pandemics? Sociology of Health and Illness 35 (2): 167-173.

Fairlie, Robert in Desai Sameeksha (2020): 2019 Early-Stage Entrepreneurship in the United States, Kauffman Indicators of Entrepreneurship, Ewing Marion Kauffman Foundation: Kansas City. Dostopno prek https:/indicators.kauffman. org/wp-content/uploads/sites/2/2020/05/2019_Early-Stage-EntrepreneurshipNational-and-State-Report_final.pdf, 30. 7.2021.

Goldin, Ian, Geoffrey Cameron in Meera Balarajan (2012): Exceptional people: How migration shaped our world and will define our future. Princeton and Oxford: Princeton University press.

Greenaway, Christina in Brian D. Gushulak (2017): Pandemics, migration and global health security. V: Philippe Bourbeau (ur.): Handbook on Migration and Security, 316-336. Cheltenham: Edward Elgar Publishing.

Guadagno, Lorenzo (2020): Migrants and the COVID-19 epidemic: an initial analysis. IOM. Dostopno prek https://publications.iom.int/system/files/pdf/mrs-60. pdf, 30. 7. 2021.

Molnar, Petra (2020): Technology, migration and illness in the times of COVID-19. Dostopno prek https://edri.org/our-work/technology-migration-and-illness-inthe-times-of-covid-19/, 30. 7. 2021.

Pajnik, Mojca, Veronika Bajt, Sanja Herič (2010): Migranti na trgu dela v Sloveniji, Dve domovini/Two Homelands (31): 151-167. Dostopno prek http://twohomelands.zrc-sazu.si/uploads/articles/1603711694_Pajnik_Bajt_Heric_Migranti\%20 na\%20trgu\%20dela.pdf, 30. 7. 2021.

Pajnik, Mojca in Veronika Bajt (2010): Migrant remittances in times of economic 
decline: Coping with protectionist policies in Slovenia, Migration Letters 7 (2), 179-189.

Pajnik, Mojca (ur.) (2015): Rasizem: razrezani svet. ČKZ - Časopis za kritiko znanosti (260).

Pajnik, Mojca in Birgit Sauer (ur.) (2017): Populism and the Web: Communicative Practices of Parties and Movements in Europe, Routledge.

Panda, Rajaram (2009): Migration Remittances: The Emerging Scenario, India Quarterly 65 (2) (April-June 2009), 167-183.

Pertek, Sandra, Jenny Phillimore in Pip McKnight (2020): Forced migration, SGBV and COVID-19 Understanding the impact of COVID-19 on forced migrant survivors of SGBV, Refugee Women Connect, University of Birmingham, Institute for Research into Superdiversity. Dostopno prek https://www.birmingham.ac.uk/ Documents/college-social-sciences/social-policy/iris/2020/sgbv-covid-19.pdf, 30. 7. 2021.

Ploštajner, Klemen (2021): \#Ostanidoma: ali mit o istem čolnu V: \#Ostani doma. Migracije, begunci in Covid-19. Maribor: Kulturni center, 95-99.

Samadar, Ranabir (ur.): Borders of an Epidemic: COVID 19 and Migrant Workers, Calcutta Research Group. Dostopno prek http://www.mcrg.ac.in/CRG_COVID19/Covid_Migrant_Workers_Publications.asp, 30.7.2021.

Scott, Penelope, Dennis Odukoya in Hella von Unger (2014): The classification of "migrants" as a discursive practice in public health: a sociology of knowledge approach, Discussion Paper No. SP III 2014-601, Berlin: WZB, Vol. SP III 2014-601. Dostopno prek https://www.econstor.eu/bitstream /10419/96511 /1/784945160.pdf, 30. 7. 2021.

Zafošnik, Anja (2021): S terena: Delo z begunci na Balkanskem polotoku v času širjenja Covida-19, V: \#Ostani doma. Migracije, begunci in Covid-19. Maribor: Kulturni center, 53-60.

Zavratnik, Simona, Rebeka Falle Zorman, Živa Broder (2017): Javno mnenje in migracije: mehanizmi klasifikacij in »begunska kriza«. Teorija in praksa 54 (5): 857-884.

Zavratnik, Simona in Sanja Cukut Krilić (2020): Digitalni begunci. Transformacije migracijskih poti ali ko pametni telefon nadomesti kovček. Ljubljana: Založba FDV in Založba ZRC.

Zavratnik, Simona (2021): Mask'n'ball: polarizirana stališča in berlinske refleksije. V: \#Ostani doma. Migracije, begunci in Covid-19. Maribor: Kulturni center, 78-83.

Zavratnik, Simona in Sanja Cukut Krilić (2021): Migracije v času pandemije Covid19: meje mobilnosti in družbene neenakosti. Teorija in praksa 58 (3): 72-87.

Zavratnik, Simona in Špela Perner (2021): Sezonsko delo: pivo, solata in natakar, ki ju prinese na mizo. V: \#Ostani doma. Migracije, begunci in Covid-19. Maribor: Kulturni center, 49-52.

Zavratnik Zimic, Simona (2004): Migration trends in selected EU applicant countries (6). Slovenia: the perspective of a country on the 'Schengen periphery'. Vienna: International Organization for Migration.

Yang, Dean (2011): Migrant Remittances, Journal of Economic Perspectives 25 (3): $129-152$. 


\section{VIRI}

Cukut Krilić, Sanja (2020): Recenzija zbornika: Meje epidemije: Covid-19 in migrantski delavci in delavke. Dostopno prek https:/virusnimameja.com/2020/05/21/ recenzija-zbornika-meje-epidemije-Covid-19-in-migrantski-delavci-in-delavke/, 30. 7. 2021.

Fairlie, Robert in Desai Sameeksha (2021): National Report on Early-Stage Entrepreneurship in the United States: 2020, Kauffman Indicators of Entrepreneurship, Ewing Marion Kauffman Foundation: Kansas City. Dostopno prek https://indicators.kauffman.org/wp-content/uploads/sites/ 2/2021/03/2020_ Early-Stage-Entrepreneurship-State-Report.pdf, 30. 7. 2021.

Human right Watch (2020): Covid-19 Fuelling Anti-Asian Racism and Xenophobia Worldwide", UN Press Note, 12. Maj 2020. Dostopno prek https://www.hrw. org/news/2020/05/12/covid-19-fueling-anti-asian-racism-and-xenophobiaworldwide, 30. 7. 2021.

ILO - International Labour Organization (2020): Protecting migrant workers during the COVID-19 pandemic. Recommendations for Policy-makers and Constituents. Dostopno prek https://www.ilo.org/global/topics/labour-migration/publications/WCMS_743268/lang-en/index.htm, 30. 7. 2021.

ILO (2020): ILO Monitor: COVID-19 and the world of work. Third edition, 29 April 2020. Dostopno prek https://www.ilo.org/wcmsp5/groups/public/@dgreports /@dcomm/documents/briefingnote/wcms_743146.pdf, 30.7.2021.

ILO (2021): World Employment and Social Outlook: Trends 2021 International Labour Office - Geneva. Dostopno prek https://www.ilo.org/wcmsp5/groups/ public/---dgreports/--dcomm/---publ/documents/publication/wcms_795453. pdf, 30. 7. 2021.

IMF - International Monetary Fund (2021): World Economic Outlook: Managing Divergent Recoveries. Washington, DC, April. Dostopno prek https://www. imf.org/en/Publications/WEO/Issues/2021/03/23/world-economic-outlookapril-2021, 30. 7. 2021.

IOM - International Organization for Migration (2020a): World Migration Report, 2020. Dostopno prek https://worldmigrationreport.iom.int/, 30. 7. 2021.

IOM (2020b): Countering xenophobia and stigma to foster social cohesion in the Covid-19 response and recovery. Issue brief, 14. July 2020. Dostopno prek https://www.iom.int/sites/default/files/documents/countering_xenophobia_ and_stigma_130720.pdf, 30.7. 2021.

IOM (2021a): Covid-19 and Mobility, Statement, 25. 3. 2021. Dostopno prek https:// www.iom.int/sites/default/files/covid19-response/institutional_statement_ covid19_03-20215.pdf, 30. 7.2021.

IOM (2021b): Strategic Response and Recovery Plan COVID-19, January - December 2021. Geneva. Dostopno prek https://reliefweb.int/report/world/iom-strategic-response-and-recovery-plan-covid-19-january-december-2021, 30. 7. 2021.

IOM (2021c): COVID-19 Impact on Migrant Economic Contributions, Issues brief, 15. June 2021. Dostopno prek https://www.iom.int/sites/default/files/documents/issue_brief_covid-19_impact_on_migrant_economic_contributions.pdf, 30. 7. 2021. 
McDonnell, Emily (2020): Will COVID-19 finally force us to reconsider the Global (Im)mobility regime. Dostopno prek https://rli.blogs.sas.ac.uk/2020/04/16/ will-covid-19-finally-force-us-to-reconsider-the-global-immobility-regime/, 30. 7. 2021.

Mežnarić, Silva (1986): Bosanci: A kuda idu Slovenci nedeljom. Ljubljana: Republiška konferenca ZSMS.

MPI in IOM (2021): Covid-19 and the State of Global Mobility, 2021, dostopno prek https://publications.iom.int/books/covid-19-and-state-global-mobility-2020, 30. 7. 2021.

MPI (2021): Immigrant and Other U.S. Workers a Year into the Pandemic. Issues brief, June 2021. Dostopno prek https://www.migrationpolicy.org/sites/default /files/publications/covid19-recession-states-brief_final.pdf, 30. 7. 2021.

OECD (2010): Entrepreneurship and Migrants, Report by the OECD Working Party on on SMEs and Entrepreneurship, OECD.

OECD (2020): Contribution of migrant doctors and nurses to tacking the COVID-19 crisis in OECD countries, 13 May 2020. Dostopno prek Contribution of migrant doctors and nurses to tackling COVID-19 crisis in OECD countries, 30. 7. 2021.

UNCTAD, United Nations Conference on Trade and Development: Covid-19 and Tourism, 2021. Dostopno prek https://unctad.org/system/files/official-document/ditcinf2021d3_en_0.pdf., 30.7.2021.

UNHCR (2020): Live blog: Refugees in the Covid-19 crisis. Dostopno prek https:// www.unhcr.org/news/stories/2020/4/5e79e2410/live-blog-refugees-Covid19-crisis.html, 30. 7. 2021.

UN Human Rights Office (2020): COVID-19 does not discriminate; nor should our response. 20 March 2020. Dostopno prek https://www.ohchr.org/EN/News Events/Pages/DisplayNews.aspx?NewsID=25730\&LangID=E, 30. 7. 2021.

UNWTO (2021): Global economy could lose over $\$ 4$ trillion due to COVID-19 impact on tourism, 30 June 2021. Dostopno prek https://www.unwto.org/news /global-economy-could-lose-over-4-trillion-due-to-covid-19-impact-on-tourism, 30. 7. 2021.

UN Food and Agriculture Organisation: Migrant workers and the COVID Pandemic, 7 April 2020. Dostopno prek http://www.fao.org/3/ca8559en/CA8559EN.pdf, 30. 7. 2021.

World Bank (2020): COVID-19 to Add as Many as 150 Million Extreme Poor by 2021. Dostopno prek https://www.worldbank.org/en/news/press-release /2020/10/07/covid-19-to-add-as-many-as-150-million-extreme-poor-by-2021, 30. 7. 2021.

World Bank (2020a): The World Bank Annual Report 2020: Supporting Countries in Unprecedented Times. World Bank, Washington, DC.

World Bank (2020b): Phase II: COVID-19 Crisis through a Migration Lens Migration and Development Brief 33. Dostopno prek https://www.knomad.org/sites/ default/files/2020-11/Migration\%20\%26\%20Development_Brief\%2033.pdf, 30. 7. 2021. 
World Bank (2021): Resilience COVID-19 Crisis through a Migration Lens, Migration and Development Brief 34 May 202. Dostopno prek https://www.knomad.org/ sites/default/files/2021-05/Migration\%20and\%20Development\%20Brief\%20 34_1.pdf, 30. 7. 2021.

ZRSZ (2021): Zavod Republike Slovenije za zaposlovanje, Podatki o izdanih delovnih dovoljenjih, osebna korespondenca, julij 2021. 